\title{
The effect of processing treatments on the rumen microbial digestion in vitro of skimmilk powder protein
}

\author{
Eeva-Lissa Syväoja and Matti Kreula \\ Biochemical Research Institute, Kalevankatu, 56 B, 00180 Helsinki 18, Finland
}

\begin{abstract}
The microbial degradation of the protein of skimmilk powders manufactured and treated in different ways (high-, medium-, and low-heat spray, instant, roller, formaldehyde-treated spray) and milk powder products (skimmilk powder-wheat flour granules, skimmilk powder-barley flour pellets) was determined in anaerobic, rumensimulating conditions in vitro. The tests showed that milk protein was decomposed rapidly and extensively in rumen fluid buffer. The heat treatment had a slight $\mathrm{N}$ solubility-reducing effect. Formaldehyde treatment decreased the degradation of the protein at the beginning of the incubation, but this effect became smaller as incubation proceeded. After $48 \mathrm{~h}$ the $\mathrm{N}$ solubility of the treated skimmilk powder was about the same as that of untreated spray powder. The variation in the in vitro $\mathrm{N}$ solubility of formaldehyde-treated skimmilk powder was greater than with the other powders and products.

The skimmilk powder-wheat flour granules were hard products which remained indigestible for several hours. At the end of the microbial digestion test the addition of skimmilk powder increased the $\mathrm{N}$ solubility of wheat flour protein.

On the basis of the results obtained from the digestion test on a pelleted skimmilk powder-barley flour product it can be assumed also that the addition of skimmilk powder caused an increase in the $\mathrm{N}$ solubility of barley flour protein.
\end{abstract}

\section{Introduction}

The significance of protein to the ruminant is decisively determined by its decomposition in the rumen. Those feed proteins which are soluble in the rumen fluid are fermented very rapidly (McDonald 1952).

Casein is known to decompose extensively in the rumen fluid (PEARson and Smith 1943, Chalmers et al. 1954. Ferguson et al. 1967), and so its utilisation is less efficient than that of many other proteins generally used in the feed of ruminants. We have been unable to find any reports on the utilisation of milk powder as such by adult ruminants in the literature. It is of course true that the feeding of milk protein to a mature ruminant is both ureasonable and uneconomical. Milk powder is, as regards its solubility, like casein, but it contains easily soluble carbohydrate, and this may promote the utilisation of the protein in the rumen.

The decomposition of protein in the rumen can be prevented by different processes (heating, grinding, pelleting, rolling) or chemical treatments. The idea here is to shorten the time spent by the protein in the rumen or to inhibit 
the proteolytic activity of the rumen microbes. Several studies, particularly on the protection of casein with formaldehyde, have been performed (FERGUSON et al. 1967, Hagemeister and Pfeffer 1973, Hemsley et al. 1973, Faichney 1974, Kellaway et al. 1974), according to which the protection increased the amount of protein passing into the lower digestive tract, and decreased the nitrogen losses.

In the present study the degradation of the protein of skimmilk powders prepared in different ways (spray, roller, instant), formaldehyde-protected skimmilk powder, wheat flour granules containing various amounts of skimmilk powder, and skimmilk powder-barley flour pellets was investigated in in vitro experiments which simulated rumen conditions. These experiments formed a preliminary investigation for the following studies which elucidate the value of untreated and formaldehyde-treated milk protein as a protein source for dairy cows with high milk production (SYRJÄL Ä et al. 1978 a), and the utilization of untreated and formaldehyde-treated skimmilk powder and skimmilk powder-barley pellets by ruminants (SYRJÄLÄ et al. 1978 b).

\section{Materials and Methods}

In the in vitro experiments the microbial digestion of the protein of skimmilk powders $^{\mathbf{x}}$ dried in different ways and at different temperatures was studied. The prepasteurisation times for the high-heat spray, medium-heat spray, low-heat spray, roller and instant powders prepared for this test were $93^{\circ} \mathrm{C} / 9$ $\min , 85^{\circ} \mathrm{C} / 15 \mathrm{~s}, 68^{\circ} \mathrm{C} / 15 \mathrm{~s}, 80^{\circ} \mathrm{C} / 15 \mathrm{~s}$ and $80^{\circ} \mathrm{C} / 15 \mathrm{~s}$, respectively. The solubility index (determined by the ADmi method) of the roller powder was 9.90 $\mathrm{ml}$ and the other samples below $0.05 \mathrm{ml}$. The content of undenatured whey protein nitrogen (determined by the ADMI method) was 9.8, 5.3, 0.4, 6.3 and $0.9 \mathrm{mg}$ per $\mathrm{g}$ skimmilk powder prepared by low-, medium-, high-heat, instant and roller processing. Formaldehyde-treated medium-heat spray powder contained $0.4 \mathrm{~g}$ formaldehyde per $100 \mathrm{~g}$ protein.xx The granulated milk powder preparations $^{\mathrm{x} o}$ E-0, E-25, E-50 and E-75 contained 0, 25, 50 and $75 \%$ skimmilk powder and 100, 75, 50 and $25 \%$ wheat flour, respectively. They were prepared by an extruding process, in which the heating time ranged from a few seconds to some tens of seconds, the maximum temperatures for E-0, E-25, E-50 and E-75 being $162,135,128$ and $120^{\circ} \mathrm{C}$, respectively. The pelleted milk powder product $^{\mathrm{xo}}$ contained $30 \%$ skimmilk powder and $70 \%$ barley flour. The heat treatment during pelleting was $60-70^{\circ} \mathrm{C}$ for a few seconds.

Fresh rumen fluid was obtained, from a ram on standard feed and fitted with a rumen fistula, less than 30 minutes before the start of each test series.

The determinations of the extent of decomposition of protein were performed using the first part of the two-stage method of TILley and TERry (1963), according to which the samples were digested in a rumen fluid buffer under strictly controlled and standardised anaerobic conditions for two days. The second stage, that is pepsin- $\mathrm{HCl}$ digestion, was not performed, with the

\footnotetext{
x Manufactured by Kuivamaito Oy, Lapinlahti, Finland

xx " $\quad$ Farmos Yhtymä, Turku, "

xo " Vaasan Höyrymylly, Helsinki, "
} 
exception of a few samples, so that the total digestibility of the samples on the basis of dry matter or organic substance was not determined. Sub-samples were taken after 2, 24 and 48 hours' incubation. Total nitrogen (TN), watersoluble nitrogen (WSN) and soluble protein nitrogen (SPN) in the samples were determined by the classical Kjeldahl method, using selenium as catalyst. Protein was precipitated with $10 \%$ trichloracetic acid. Non-protein nitrogen (NPN) was obtained as the difference between WSN and SPN. Ammonia determinations were performed mainly with an ammonia electrode (Orion), and also by the Conway method (Conway 1962).

\section{Results}

The course of the digestion of the skimmilk powders and milk-powder products in the in vitro incubation with rumen fluid is seen in Figures $\mathbf{1}$ and 2 . The results are means of $4-10$ separate determinations. Fig. 1 gives the proportion of WSN and Fig. 2 that of NPN as a per cent of the TN.

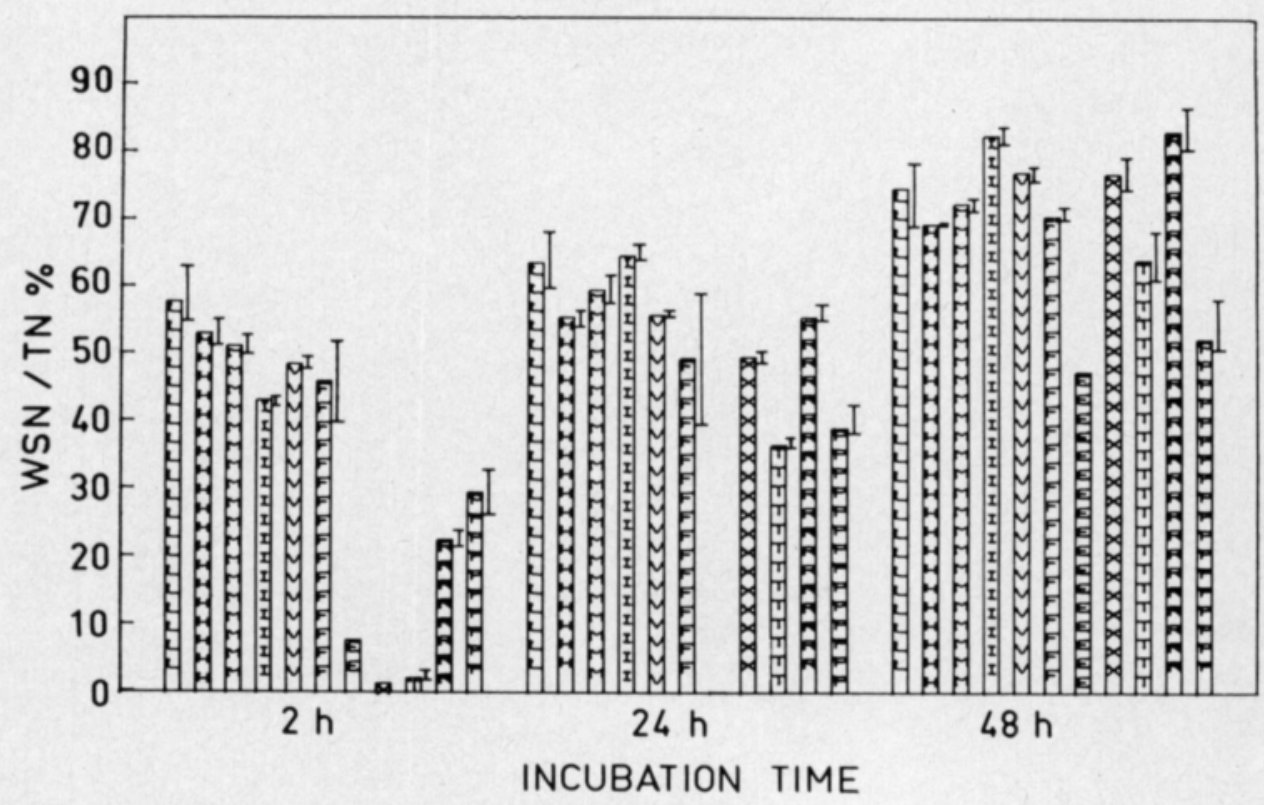

Fig. 1. The proportion of water-soluble nitrogen (WSN) as a percent of the total nitrogen (TN) in in vitro microbial digestion tests with different skimmilk powders and skimmilk powder products. The variation range of the results is given as a line beside each column. The symbols inside the columns mean:

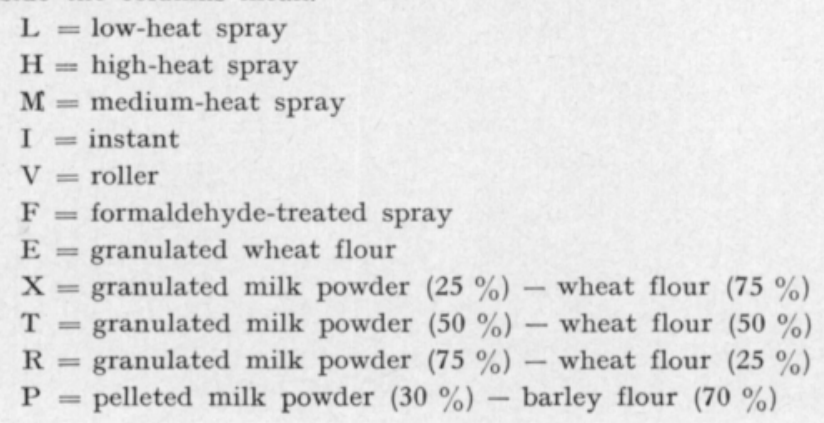




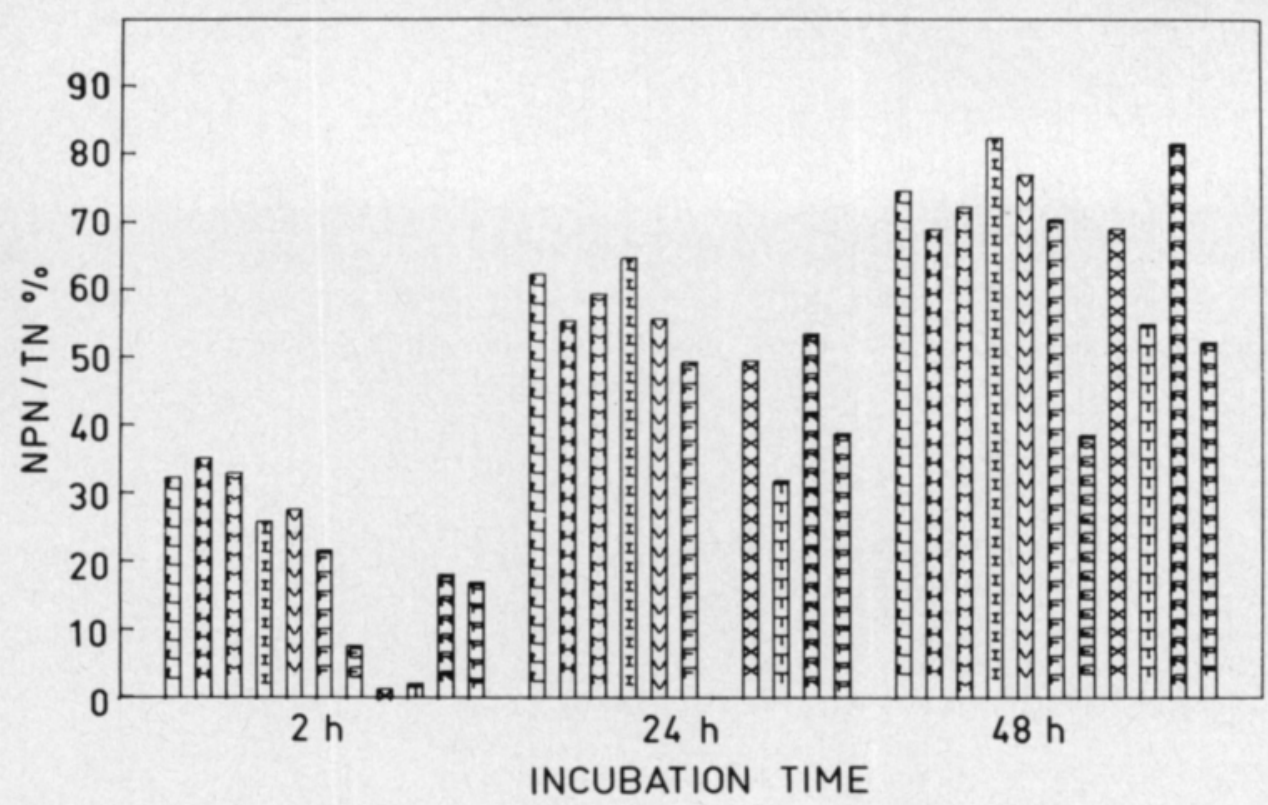

Fig. 2. The proportion of non-protein nitrogen (NPN) as a percent of the total nitrogen (TN) in in vitro microbial digestion tests with skimmilk powder samples. The symbols inside the columns are the same as in Fig. 1.

Of the TN of untreated skimmilk powders, $43-58 \%$ was found in watersoluble form after an incubation of $2 \mathrm{~h}$. Of the WSN, 20-25\% was still, however, SPN. Heat treatment had a slight protecting effect. The nitrogen (N) solubility of the high-, medium- and low-heat spray powders was 53,51 and $58 \%$ respectively. At this incubation stage the formaldehyde treatment decreased the $\mathrm{N}$ solubility by an average of $4 \%$ units, that is to $47 \%$.

Variations in the in vitro $\mathrm{N}$ solubility of formaldehyde-treated milk powder proved greater than in that of high-, medium- and low-heat spray powders. Therefore the range of the $\mathrm{N}$ solubility results with powders is also given in Fig. 1.

After $24 \mathrm{~h}$ the $\mathrm{N}$ solubility of the skimmilk powder samples was on the average 55-65\%. Heating and formaldehyde treatment further decreased the degradation of protein. The $\mathrm{N}$ solubility of the roller powder $(56 \%)$, which had become partly denatured by the heat treatment, and the high-heat spray powder $(55 \%)$ was lower than that of the low-heat $(64 \%)$, medium-heat $(59 \%)$ and instant $(65 \%)$ powders. Formaldehyde treatment decreased the $\mathrm{N}$ solubility by $10 \%$ units. The solubilised $\mathrm{N}$ was then almost entirely NPN, of which $90-100 \%$ was ammonia; after two days' incubation the former figure had risen to about $\mathbf{7 0 - 8 0 \%}$ (Table 1). The protective effect of formaldehyde decreased during the incubation: after two days the $\mathrm{N}$ solubility of the treated spray-milk powder was about the same as that of the untreated powder.

The digestion of the granulated products containing $0,25,50$ and $75 \%$ skimmilk powder was slow at first. After one day, $0,50,36$ and $56 \%$ respectively 
Table 1. The proportion of ammonium nitrogen $\left(\mathrm{NH}_{3}-\mathrm{N}\right)$ as a percent of the non-protein nitrogen (NPN) after various incubation times in in vitro microbial digestion tests in rumen fluid buffer. E-0, E-25, E-50 and E-75 are extruded milk powder-wheat flour granules containing $0,25,50$ and $75 \%$ skimmilk powder respectively. The pelleted sample contained $30 \%$ skimmilk powder, the rest being barley flour.

\begin{tabular}{|c|c|c|c|}
\hline $\begin{array}{l}\text { Milk powder } \\
\text { sample }\end{array}$ & $2 \mathrm{~h}$ & $\begin{array}{l}-\mathrm{N} / \mathrm{NP} \\
24 \mathrm{~h}\end{array}$ & $48 \mathrm{~h}$ \\
\hline Low-heat spray $\ldots \ldots \ldots \ldots \ldots \ldots \ldots$ & 34.3 & 100 & 99.0 \\
\hline High-heat spray . ....................... & 30.4 & 94.7 & 160 \\
\hline Medium-heat spray .................... & 33.0 & 90.0 & 100 \\
\hline 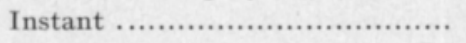 & 26.4 & 97.3 & 100 \\
\hline 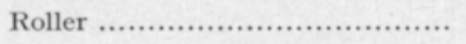 & 26.8 & 100 & 100 \\
\hline E-0 & 26.7 & 0 & 61.3 \\
\hline 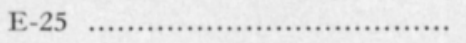 & 0 & 0 & 82.2 \\
\hline 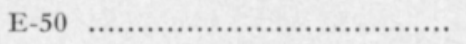 & 0 & c & 86.0 \\
\hline 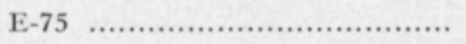 & 18.8 & 72.7 & 90.3 \\
\hline 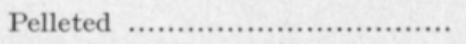 & 29.1 & 91.5 & 100 \\
\hline Formaldehyde-treated ................. & 29.1 & 93.7 & 100 \\
\hline
\end{tabular}

of the TN or these samples was in soluble form, and after two days $47,77,64$ and $83 \%$. The extruded product containing no milk powder was not as resistant as those containing milk powder. After two hours' incubation almost $\mathbf{8} \%$ of the TN was in water-soluble form, which was subsequently used in microbial cell synthesis, since after 24 hours no soluble $\mathrm{N}$ was found. Ammonia was formed in only the 0 and $75 \%$ milk powder samples after two hours' incubation and after $24 \mathrm{~h}$ in only the $\mathbf{7 5} \%$ sample. After $48 \mathrm{~h}$ the WSN was not, however, solely ammonium nitrogen as was the case with skimmilk powders, as part of it was still SPN.

The barley flour pellets, which contained $30 \%$ skimmilk powder, were not as resistant as the extruded products, and were decomposed in the rumen fluid buffer much more quickly. After the incubation times used the proportion of the WSN of the TN was 30,39 and $52 \%$, of which $91 \%$ was ammonium nitrogen after $24 \mathrm{~h}$ and $100 \%$ after $48 \mathrm{~h}$.

\section{Discussion}

The results showed that readily-soluble skimmilk powder protein was decomposed very rapidly in the rumen fluid in vitro due to microbial activity. The end product was ammonia. El Shazly (1952 a, b) observed that casein was decomposed in rumen fluid in vitro and in vivo in the same way. In the decomposition process the first stage was the proteolytic decomposition into amino acids, which in turn were deaminated. The amount of ammonia in the rumen fluid showed the degree of protein decomposition. When casein was given via a fistula straight into the abomasum or duodenum its digestibility was good and the animal was able to use the nitrogen better than that of casein entering via the rumen (EGAN and MoIr 1965, REIS 1969, PAPAS et al. 1971, MAcraE et al. 1972). 
Owing to its high solubility, skimmilk powder probably does not remain in the rumen as long as $48 \mathrm{~h}$. In the in vitro experiments the two-hour incubation was also obviously too short for the development of microbial activity under the new conditions. When examining the results after the $24 \mathrm{~h}$ incubation it is found that the $\mathrm{N}$ solubility of the high-heat spray powder was $3 \%$ units lower than that of medium-heat powder and $5 \%$ units lower than that of lowheat powder. The high-heat treatment $\left(93^{\circ} \mathrm{C} / 9 \mathrm{~min}\right)$ had a slight degradationreducing effect compared with the medium-heat $\left(85^{\circ} \mathrm{C} / 15 \mathrm{~s}\right)$ or low-heat $\left(68^{\circ} \mathrm{C} / 15 \mathrm{~s}\right)$ treatments. A brief heat treatment, which did not greatly denature proteins, had no effect on the fermentation extent of the product. After the $24 \mathrm{~h}$ incubation the $\mathrm{N}$ solubility of the roller powder was the same as that of the high-heat spray powder. When using the roller method, protein is partly denatured.

Skimmilk powder however was not degraded to the same extent as casein in rumen fluid. Hume (1974) observed that the extent of degradation of casein in the rumen fluid was as high as $91 \%$.

Hemsley et al. (1973) found that $86 \%$ of untreated casein was decomposed in rumen fluid, but when the casein contained $1 \%$ or more formaldehyde it protected the product from microbial decomposition. In the present study, treatment with formaldehyde $(0.4 \mathrm{~g} / 100 \mathrm{~g}$ protein) decreased the $\mathrm{N}$ solubility of medium-heat spray milk powder by an average of $10 \%$ units after 24 hours' incubation. It is true, however, that the variation in the solubility results from the formaldehyde-treated milk powder samples was larger than with the other samples studied. This did not appear to be due to uneven distribution of formaldehyde in the sample, since according to the manufacturer the product was of uniform composition. The $\mathrm{N}$ solubility-reducing effect of formaldehyde decreased, however, in longer incubations. After $48 \mathrm{~h}$ no real difference was found in the $\mathrm{N}$ solubility of treated and untreated milk powder. The proportion of ammonium nitrogen of the TN or WSN of the treated powder after 2 hours' incubation was smaller than that of the untreated milk powder, but after 24 and 48 h no difference was found. Even very small amounts of free formaldehyde in the sample interfered with the determination of ammonia by various methods. According to the manufacturer the treated milk powder did not contain free formaldehyde.

ChAlmers et al. (1954) observed that casein could be processed by heating or browning so that smaller amounts of ammonia were formed in the rumen and the utilisation of protein became more efficient. The authors' opinion was that although the heat treatment decreased the biological value of the protein, the decrease did not have the same importance in the feed of ruminants as in that of non-ruminants. The extruded milk powder-wheat flour granules (E-0, E-25, E-50 and E-75) also underwent a brief heat treatment. Wheat flour was used to convert the skimmilk powder to a granulated, rather hard product which does not dust during handling, with a degradation in rumen fluid lower than that of untreated milk powder. The higher the milk powder to wheat flour ratio, the smaller the process variables were to be. In spite of the milder processing the colour of samples E-50 and E-75 in particular was brown, and they had a distinct caramel flavour. The biological value of the protein may 
have been reduced as a result of the Browning reaction. The products were especially hard, too. At the beginning of the microbial digestion test they remained almost whole for several hours. After 24 hours' incubation ammonia was formed only in sample E-75. However, 47-83\% of the total TN of the extruded samples was in water-soluble form (Fig. 1), of which $0-1.7 \%$ was SPN (Fig. 2). The decomposition of the total proteins had started, but the amino acids had not yet been deaminated. It should be noted that after 24 and 48 hours' incubation the amount of NPN of samples E-25 and E-75 was larger than when corresponding amounts of skimmilk powder and granulated wheat flour were incubated separately. Thus it is evident that the addition of skimmilk powder caused the increase in the $\mathrm{N}$ solubility of wheat flour protein in the rumen fluid buffer. In contrast, the decomposition of the $50 \%$ skimmilk powder-containing granules (E-50) after 24 and 48 hours' incubation was the same as the decomposition of the corresponding amounts of skimmilk powder and granulated wheat flour.

Pelleting did not reduce the rate of digestion of the sample in the rumen fluid. No pelleted barley flour was available for digestion determination, but on the basis of these results it can be expected that the addition of milk powder to barley flour would also increase the $\mathrm{N}$ solubility of barley flour protein in rumen fluid buffer.

\section{REFERENCES}

Chalmers, M. I., Cuthbertson, D. P. \& Synge, R. L. M. 1954. Ruminal ammonia formation in relation to the protein requirement of sheep. 1. Duodenal administration and heat processing as factors influencing fate of casein supplements. J. Agric. Sci. 44: 254-262.

Conway, E. J. 1962. In microdiffusion analysis and volumetric error. Crosby Lockwood \& Son Ltd. London. p. 111, 162.

EgAN, A. R. \& MorR, R. J. 1965. Nutritional status and intake regulation in sheep. 1. Effects of duodenally infused single doses of casein, urea, and propionate upon voluntary intake of a low-protein roughage by sheep. Aust. J. Agric. Res. 16:437-449.

FAICHNEY, G. J. 1974. Effects of formaldehyde treatment of casein and peanut meal supplements on amino acids in digesta and plasma of lambs and sheep. Aust. J. Agr. Res. 1974 25: 583-598.

Ferguson, K. A., Hemsley, J. A. \& Reis, P. J. 1967. Nutrition and wool growth. The effect of protecting dietary protein from microbial degradation in the rumen. Aust. J. Sci. 30: $215-217$.

Hagemeister, H. Pfeffer, E. 1973. Der Einfluss von formaldehydbehandeltem Kasein und Sojaschrot auf die mikrobiellen Proteinumsetzungen in den Vormägen und die Aminosäure-Versorgung im Darm der Milchkuh. Z. Tierphysiol. Tierernähr. Futtermittelk. 31: $275-290$.

Hemsley, J. A., Reis, P. J. \& Downes, A M. 1973. Influence of various formaldehyde treatments on the nutritional value of casein for wool growth. Aust. J. Biol. Sci. 26: $961-$ 972.

Hume, I. D. 1974. The proportion of dietary protein escaping degradation in the rumen of sheep fed on various protein concentrates. Aust. J. Agric. Res. 25: 155-165.

Kellaway, R. C., Ranawana, S. S. E., Buchanan, J. H. \& Smart, L. D. 1974. Effect of nitrogen source in the diet on milk production and amino-acid uptake by the udder. J. Dairy Res. 41: 305-314. 
Macrae, J. C., Ulyatt, M. J., Pearce, P. D. \& Hendtlass, J. 1972. Quantitative intestinal digestion of nitrogen in sheep given formaldehyde-treated and untreated casein supplements. Br. J. Nutr. 27: 39-50.

McDonald, I. W. 1952. The role of ammonia in ruminal digestion of protein. Biochem. J. 51: $86-90$.

Papas, A., Nimrick, K., Owens, F. N. \& Hatfield, E. E. 1971. Effect of abomasally-infused casein on feed intake. J. Anim. Sci. 33: 1169.

Pearson, R. M. \& Smith, J. A. B. 1943. The utilization of urea in the bovine rumen. 3. The synthesis and breakdown of protein in rumen ingesta. Biochem. J. 37: 153-164.

REIS, P. J. 1969. The growth and composition of wool growth by the abomasal administration of varying amounts of casein. Aust. J. Biol. Sci. 22: 745-759.

ShazLy, K. el-. 1952 a. Degradation of protein in the rumen of the sheep. 1. Some volatile fatty acids, including branched-chain isomers found in vivo. Biochem. J. 51: 640-647.

- - el-. 1952 b. Degradation of protein in the rumen of the sheep. 2. The action of rumen micro-organisms on amino-acids. Biochem. J. 51:647-653.

Syrjälä, L., Poutiainen, E \& Koskela, V.-H. 1978 a. Untreated and formaldehyde-treated skimmilk powder as a protein supplement for dairy cows. J. Scient. Agric. Soc. Finl. 50: $155-165$.

- - , Syväoja, E.-L. \& Boman, M. 1978 b. Utilization of untreated and formaldehydetreated skimmilk powder and skimmilk powder-barley pellets by ruminants. J. Scient. Agric. Soc. Finl. 50: 166-176.

Tilley, J. M. A. \& Terry, R. A. 1963. A two-stage technique for the in vitro digestion of forage crops. J. Brit. Grassl. Soc. 18: 104-111.

Ms received March 13, 1978

\title{
SELOSTUS
}

\section{Erilaisten käsittelyjen vaikutus rasvattoman maitojauheen typen liukoisuuteen in vitro pötsinestepuskurissa}

\author{
Eeva-Lirsa Syväoja ja Matri Kreula \\ Biokemiallinen Tutkimuslaitos, Kalevankatu 56 B, 00180 Helsinki 18
}

Eri tavoin valmistettujen ja käsiteltyjen rasvattomien maitojauheiden (high-, medium-, low-heat spray, instant, valssi, formaldehydikäsitelty spray) sekä maitojauhevalmisteiden (maitojauhe-vehnäjauhogranulaatit, maitojauhe-ohrajauhopelletti) typen liukoisuus määritettiin anaerobisissa pötsiä mukailevissa olosuhteissa in vitro.

Tulokset osoittivat, että maitojauheproteini hajaantui nopeasti ja runsaasti pötsinestepuskurissa. Kuumennuskäsittely, joka denaturoi osittain maitojauheproteiinia valmistusvaiheen aikana, alensi typen liukoisuutta lievästi.

Formaliinikäsittely aikaansai liukoisuuden alenemisen inkuboinnin alkuvaiheessa, mutta liukoisuutta estävä vaikutus pieneni inkubaation kuluessa. Kahden vuorokauden kuluttua käsitellyn maitojauheen liukoisen typen osuus kokonaistypestä oli jokseenkin sama kuin käsittelemättömän spray-kuivatun maitojauheen. Vaihtelut formaliinikäsitellyn maitojauheen liukoisuuksissa osoittautuivat suuremmiksi kuin muiden näytteiden.

Maitojauhe-vehnäjauhogranulaatit olivat kovia, useita tunteja sulamattomina pysyviä tuotteita. Kahden vuorokauden sulatuksen jälkeen maitojauhelisäys oli aikaansaanut vehnäjauhoproteiinin liukoisuuden lisääntymisen.

Maitojauhe-ohrajauhopellettiä pötsinestepuskurissa sulatettaessa todettiin, että pelletoiminen ei hidastanut maitojauheen typen sulavuutta. Tulosten perusteella voidaan myös olettaa, että maitojauhelisäys aikaansai ohrajauhoproteiinin liukoisuuden lisääntymisen. 